\title{
UPAYA MENINGKATKAN HASIL BELAJAR PENDIDIKAN AGAMA HINDU TENTANG WARIGA MELALUI PENERAPAN MODEL PEMBELAJARAN KOOPERATIF TEAMS GAMES TOURNAMENTS (TGT) BAGI SISWA KELAS X MIPA-7 SMAN 1 KUTA SELATAN SEMESTER 1 TAHUN PELAJARAN 2016/2017
}

\author{
Oleh : \\ I Gede Pasek Artana \\ Sekolah Menengah Atas Negeri 1 Kuta Selatan
}

\begin{abstract}
This study aims to improve the learning outcomes of Hindu and Budi Pekerti education subjects on Wariga for students of class X MIPA-7 SMA Negeri 1 Kuta Selatan through the implementation of cooperative learning model Teams Games Tournaments (TGT) held in the first semester of the academic year 2016 / 2017, which starts from September until October 2016 with the subject of research is the students of class X MIPA-7 SMA Negeri 1 Kuta Selatan 2016/2017 lesson year as many as 29 students who are Hindu. Basic Competency presented to the students is Explaining the essence of Padewasan (wariga) in the life of Hindus. This research was conducted in 2 cycles with planning, implementation, observation, and reflection on each cycle. Data collection techniques used are with the test results and observation sheet. Data analysis using comparative descriptive analysis technique by comparing the learning outcomes at initial conditions with the results achieved in each cycle, and qualitative descriptive analysis by comparing the results of observation and reflection on the cycle I and cycle II. The result of data analysis shows that there is improvement of learning quality both process and learning result. It can be seen that in the first cycle there has been an increase in the average score of 11.38 students, ie from the average score of the students at the initial conditions 66.21 to 77.59 and an increase in the average score of students 7.41 on cycle II of Average grade grade 77.59 to 85.00. While the completion of classical learning at the end of the first cycle, there was an increase of $27.59 \%$, from the initial condition that has been completed only $51.72 \%$ to $79.31 \%$, and there is an increase in learning mastery by 13, 79 from $79.31 \%$ To $93.10 \%$ in cycle II. It is based on the results of observations during the learning process and the results of the assessment of knowledge about wariga after the learning process takes place. So it is suggested to the teacher especially the subject teacher of Hindu and Budi Pekerti Education to use cooperative learning model Teams Games Tournaments (TGT) in an effort to improve the learning result of Hindu Religion and Budi Pekerti.
\end{abstract}

Keywords: Learning outcomes, cooperative learning, Teams Games Tournaments. ABSTRAK

Penelitian ini bertujuan untuk mengupayakan peningkatan hasil belajar mata pelajaran Pendidikan Agama Hindu dan Budi Pekerti tentang Wariga bagi siswa kelas X MIPA-7 SMA Negeri 1 Kuta Selatan melalui penerapan model pembelajaran kooperatif Teams Games Tournaments (TGT) yang dilaksanakan pada Semester I tahun pelajaran 2016/2017, yang dimulai dari bulan September sampai dengan bulan Oktober 2016 dengan Subjek penelitian adalah siswa kelas X MIPA-7 SMA Negeri 1 Kuta Selatan tahun 
pelajaran 2016/2017 sebanyak 29 siswa yang beragama Hindu. Kompetensi Dasar yang disampaikan pada siswa adalah menjelaskan hakikat Padewasan (wariga) dalam kehidupan umat Hindu. Penelitian ini dilaksanakan dalam 2 siklus dengan tahapan perencanaan, pelaksanaan, observasi-evaluasi, dan refleksi pada tiap-tiap siklus. Teknik pengumpulan data yang dipergunakan adalah dengan tes hasil belajar dan lembar observasi. Analisis data menggunakan teknik analisis deskriptif komparatif dengan membandingkan hasil belajar pada kondisi awal dengan hasil yang dicapai pada setiap siklus, dan analisis deskriptif kualitatif dengan membandingkan hasil observasi dan refleksi pada siklus I dan siklus II. Hasil analisis data menunjukkan bahwa terjadi peningkatan kualitas pembelajaran baik proses maupun hasil pembelajaran. Dapat diketahui bahwa pada siklus I telah terjadi peningkatan nilai rata-rata siswa sebesar 11,38 , yaitu dari nilai rata-rata siswa pada kondisi awal 66,21 menjadi 77,59 dan peningkatan nilai rata-rata siswa sebesar 7,41pada siklus II dari nilai rata-rata kelas 77,59 menjadi 85,00. Sedangkan ketuntasan belajar secara klasikal pada akhir siklus I, ada peningkatan sebesar $27,59 \%$, dari kondisi awal yang sudah tuntas hanya $51,72 \%$ menjadi $79,31 \%$, dan terdapat peningkatan ketuntasan belajar secara klasikal sebesar 13,79 dari $79,31 \%$ menjadi $93,10 \%$ pada siklus II. Hal tersebut berdasarkan atas hasil pengamatan saat proses pembelajaran dan hasil tes penilaian pengetahuan tentang wariga setelah proses pembelajaran berlangsung. Sehingga disarankan kepada guru khususnya guru mata pelajaran Pendidikan Agama Hindu dan Budi Pekerti untuk menggunakan model pembelajaran kooperatif Teams Games Tournaments (TGT) dalam upaya meningkatkan hasil belajar Pendidikan Agama Hindu dan Budi Pekerti.

\section{Kata Kunci: Hasil belajar, Pembelajaran Kooperatif, Teams Games Tournaments.}

\section{A. PENDAHULUAN}

\section{Latar Belakang Masalah}

Pendidikan pada masa sekarang ini diharapkan dapat menghasilkan sumber daya manusia yang berkualitas dan berdaya saing tinggi untuk menghadapi persaingan di era globalisasi. Salah satu indikator pendidikan berkualitas dalam membentuk sumber daya manusia adalah perolehan nilai hasil belajar siswa. Nilai hasil belajar siswa dapat lebih ditingkatkan apabila pembelajaran berlangsung secara efektif dan efisien dengan ditunjang oleh tersedianya sarana dan prasarana pendukung serta kecakapan guru dalam pengelolaan kelas dan pengusaan materi yang memadai.

Tolok ukur keberhasilan pembelajaran pada umumnya adalah hasil belajar. Hasil belajar mata pelajaran Pendidikan Agama Hindu dan Budi Pekerti di kelas X MIPA-7
SMA Negeri 1 Kuta Selatan tahun pelajaran 2016/2017 pada beberapa kompetensi dasar umumnya menunjukkan nilai yang rendah. Hal ini karena kompetensi dasar Pendidikan Agama Hindu dan Budi Pekerti di kelas X memang sarat akan materi, di samping cakupannya luas dan perlu pemahaman. Jika dilihat dari hasil tes penilaian pengetahuan harian sebagian besar masih banyak di bawah kriteria ketuntasan minimal (KKM) yang telah ditentukan yaitu sebesar 67. Dari 29 siswa yang beragama Hindu di kelas X MIPA-7, hanya 48,28\% belum mencapai ketuntasan belajar minimal, dan $51,72 \%$ siswa yang telah memenuhi standar ketuntasan minimal, sedangkan nilai rata-rata kelas pada kondisi awal sebesar 66,21 yang tentunya berada di bawah KKM yang telah ditetapkan.

Rendahnya hasil belajar Pendidikan Agama Hindu dan Budi Pekerti di kelas X 
MIPA-7 SMA Negeri 1 Kuta Selatan tahun pelajaran 2016/2017 dimungkinkan juga karena guru belum cakap dalam menggunakan metode atau pun media pembelajaran serta mendesain skenario pembelajaran yang disesuaikan dengan karakteristik materi maupun kondisi siswa yang memungkinkan siswa aktif dan kreatif. Namun sebaliknya, kecenderungan guru masih menggunakan model pembelajaran konvensional yang bersifat satu arah, cenderung kering dan membosankan sehingga kegiatan pembelajaran masih didominasi oleh guru. Pendekatan pembelajaran yang memposisikan guru sebagai pusat segalagalanya (teacher center), miskin dengan media pembelajaran, mendewakan metode ceramah, interaksi satu arah, menyebabkan siswa pasif sehingga suasana kelas menjadi tegang, dan kaku. Kondisi pembelajaran seperti itu tidak memberikan ruang kepada peserta didik untuk berkreasi sesuai dengan potensi yang dimiliki. Siswa hanya sebagai objek, bukan subjek pembelajar bahkan guru cenderung membatasi partisipasi dan kreatifitas siswa selama proses pembelajaran.

Bertumpu pada kenyataan tersebut, untuk merangsang dan meningkatkan peran aktif siswa baik secara individual maupun kelompok terhadap proses pembelajaran Pendidikan Agama Hindu dan Budi Pekerti maka masalah ini harus ditangani dengan mencari beberapa alternatif model pembelajaran yang tepat dan sesuai dengan materi yang diajarkan. Guru sebagai pengajar dan fasilitator harus mampu melakukan pembelajaran yang menyenangkan, menggairahkan sehingga memperoleh hasil yang maksimal. Salah satu diantaranya adalah model pembelajaran kooperatif Teams Games Tournaments (TGT).

\section{Rumusan Masalah}

Dalam penelitian ini dapat dirumuskan permasalahan yang diteliti yaitu : Apakah melalui Penerapan Model Pembelajaran Kooperatif Teams Games Tournaments (TGT) dapat meningkatkan hasil belajar mata pelajaran Pendidikan Agama Hindu dan Budi Pekerti tentang Wariga bagi siswa kelas XMIPA-7 SMA Negeri 1 Kuta Selatan Semester I Tahun Pelajaran 2016/2017?

\section{Tujuan Penelitian}

Secara umum tujuan dari penelitian ini adalah untuk memperbaiki proses pembelajaran Pendidikan Agama Hindu dan Budi Pekerti kelas X MIPA-7 SMAN 1 Kuta Selatan yang mengarah pada inovasi pembelajaran sehingga dapat meningkatkan hasil belajar.

Secara khusus tujuan penelitian ini adalah untuk meningkatkan hasil belajar mata pelajaran Pendidikan Agama Hindu dan Budi Pekerti tentang Wariga melalui penerapan model pembelajaran kooperatif Teams Games Tournaments (TGT) bagi siswa kelas XMIPA-7 SMA Negeri 1 Kuta Selatan Semester I Tahun Pelajaran 2016/2017.

\section{B. Landasan Teori}

\section{Teori belajar Konstruktivisme}

Piaget merupakan salah satu tokoh konstruktivisme dari Swiss, ia berpendapat bahwa anak membangun sendiri pengetahuan dari pengalaman sendiri. Pengetahuan timbul dari pengalamannya sendiri. Pengetahuan timbul dari tindakan dan sebagian besar perkembangan kognitif bergantung pada seberapa jauh anak aktif memanipulasi dan aktif berinteraksi dengan lingkungannya ( Piaget dalam Widada, 1999 : 21)

Dalam pembelajaran, Piaget menekankan pembelajaran melalui penemuan, pengalaman-pengalaman nyata dan memanipulasi langsung alat, bahan atau media belajar yang lain. Guru mempersiapkan lingkungan yang 
memungkinkan siswa dapat memperoleh pengalaman belajar yang luas. Guru bertindak sebagai fasilitator, model serta sebagai nara sumber yang tidak otoriter.

\section{Hasil Belajar Pendidikan Agama Hindu}

\section{a. Hasil Belajar}

Hasil belajar siswa menurut Hamalik ( 2003:160). meliputi tiga aspek, yaitu aspek sikap (afektif), pengetahuan (kognitif), dan keterampilan (psikomotorik).

(1) Aspek sikap (afektif), merupakan perilaku yang dilakukan peserta didik yang meliputi penerimaan, partisipasi, dan penentuan sikap, organisasi, dan pembentukan pola hidup. (2) Aspek pengetahuan (kognitif), kemampuan kognitif yang meliputi: pengetahuan, pemahaman, penerapan, analisis, sintesis, dan evaluasi. (3) Aspek keterampilan (psikomotorik), kemampuan psikomorik meliputi: persepsi, kesiapan, gerakan terbimbing, gerakan terbiasa, gerakan kompleks, gerakan penyesuaian dan kreativitas. Dalam perkembangan berikutnya, aspek pengetahuan dari taksonomi Bloom disempurnakan menjadi taksonomi Anderson yang dijadikan pedoman dalam implementasi kurikulum 2013, dengan penyempurnaan yang meliputi: mengingat, memahami, menerapkan, menganalisis, menilai dan mencipta.

Dari beberapa pemaparan pengertian yang mencakup hasil belajar diatas dapat disimpulkan bahwa hasil belajar adalah keseluruhan hasil proses pembelajaran yang dilakukan dalam kurun waktu tertentu yang ditandai dengan adanya kemampuan penguasaan konsep, perubahan sikap dan perilaku siswa serta mampu dan terampil mempraktikkan/menerapkan baik secara individu maupun secara bersama-sama dalam kehidupan bermasyarakat, dan bernegara.

\section{b. Pendidikan Agama Hindu}

Pendidikan Agama Hindu adalah usaha yang dilakukan secara terencana dan berkesinambungan dalam rangka mengembangkan kemampuan peserta didik untuk memperteguh keimanan dan ketakwaan kepada Tuhan Yang Maha Esa dan berakhlak mulia, serta peningkatan potensi spiritual sesuai ajaran agama Hindu.

Menurut buku keputusan seminar kesatuan tafsir terhadap aspek-aspek agama Hindu I-XV (1985:23-24), pendidikan agama Hindu dibagi menjadi dua yaitu : 1) Pengertian pendidikan agama Hindu di luar sekolah adalah merupakan suatu upaya untuk membina pertumbuhan jiwa masyarakat, dengan ajaran agama Hindu itu sendiri sebagai pokok materi. 2) Pengertian pendidikan agama Hindu di sekolah ialah suatu upaya untuk membina pertumbuhan jiwa raga anak didik sesuai dengan ajaran agama Hindu. Kalau dihubungkan pengertian pendidikan secara umum dengan pendidikan agama Hindu, mempunyai kaitan yang sangat erat. Pendidikan agama Hindu merupakan unit yang berperan untuk menunjang dalam pembinaan dan pertumbuhan kepribadian manusia. Pendidikan agama Hindu di luar sekolah mempunyai tujuan untuk 
menanamkan keyakinan kepada umat tentang kebenaran ajaran agama Hindu dan dijadikan landasan dalam bertingkah laku dalam kegiatan sehari-hari agar dapat mencapai keharmonisan, kesimbangan hidup manusia dengan Tuhan, antara manusia dengan manusia dan antara manusia dengan lingkungannya. Sedangkan pendidikan di sekolah adalah membentuk manusia yang astiti bhakti kepada Ida Sanghyang widhi Wasa, membentuk moral anak didik yang sesuai dengan ajaran agama Hindu.

Dari seluruh pengertian pendidikan agama Hindu yang telah diuraikan diatas, maka dapat disimpulkan bahwa pendidikan agama Hindu adalah usaha yang dilakukan dengan sengaja, berencana, terarah dan terus menerus kepada anak atau jiwa kerohanian untuk membentuk kepribadian, sikap mental atau akhlak mulia serta melaksanakan amal ketuhanan bagi umat Hindu.

\section{c. Wariga}

Wariga adalah asal kata dari wara dan ika, wara berarti hari, ika berarti itu (ika = iga). Jadi wariga adalah suatu ilmu yang menguraikan tentang persoalan hari-hari baik dan hari-hari yang buruk bagi suatu pekerjaan. Kata wariga hampir sama dengan istilah padewasan. Kata padewasaan berasal dari kata " dewasa" mendapat awalan pa dan akhiran an ( pa-dewasa-an). Dewasa artinya hari pilihan, hari baik. Padewasaan berarti ilmu tentang hari yang baik. Dewasa ayu artinya hari yang baik untuk melaksanakan sesuatu. Juga disebut Wariga yang artinya waktu yang telah ditetapkan untuk sesuatu. Dalam kamus bahasa Bali, wariga artinya ajaran tentang dewasa yaitu baik atau buruknya hari untuk melakukan sesuatu ( Sudirga,2014:78).

Padewasaan dan Wariga adalah merupakan bagian dari ilmu astronomi yang termasuk bidang Vedangga. Jadi secara hakiki fungsi dari wariga adalah pelengkap dalam ilmu agama yang bertujuan untuk memberikan ukuran atau pedoman dalam mencari dewasa. Baik buruk hari mempunyai akibat terhadap nilai hasil dan guna suatu perbuatan.

3. Model Pembelajaran Kooperatif Teams Games Tournaments (TGT) Model Pembelajaran Kooperatif Team Group Tournament dikemas dalam bentuk permainan karena bermain merupakan pemenuhan suatu kebutuhan mendasar bagi peserta didik serta sesuatu yang sangat menarik. Aktivitas belajar dengan permainan yang dirancang dalam model pembelajaran kooperatif Teams Games Tournaments (TGT) memungkinkan siswa dapat belajar lebih fokus dan rileks di samping juga dapat menumbuhkan tanggung jawab, kecekatan, kerja sama, persaingan sehat, dan keterlibatan belajar.

Karakteristik model pembelajaran kooperatif Teams Games Tournaments memunculkan adanya kelompok dan kerjasama dalam belajar, disamping itu terdapat persaingan antar individu dalam kelompok maupun antar kelompok. Oleh sebab itu penerapan model pembelajaran kooperatif Teams Games Tournaments diharapkan mampu mengatasi kejenuhan belajar, guru tidak lagi harus secara marathon menjelaskan materi 
karena waktu relatif lebih singkat dan cara melakukannya relatif lebih mudah. Kemampuan dan potensi yang dimiliki siswa cukup dengan arahan dan bimbingan guru. Pembelajaran kooperatif dengan berbagai model dikembangkan berlandaskan teori belajar Konstruktivisme. Langkahlangkah dalam pelaksanaan model pembelajaran kooperatif Teams Games Tournaments (TGT) ada 5 tahapan yaitu sebagai berikut :

1) Penyajian kelas

Pada awal pembelajaran guru menyampaikan materi dalam penyajian kelas, biasanya dilakukan dengan pengajaran langsung, berupa paparan masalah, pemberian data, pemberian contoh dan diskusi yang dipimpin guru. Tujuan peresentasi adalah untuk mengenalkan konsep dan mendorong rasa ingin tahu siswa. Pada saat penyajian kelas ini, siswa harus benar-benar memperhatikan dan memahami materi yang diberikan guru, karena akan membantu siswa bekerja lebih baik pada saat kerja kelompok.

2) Kelompok (team )

Kelompok biasanya terdiri atas empat sampai dengan lima orang siswa dengan anggota kelompok dibuat heterogen meliputi karakteristik kecerdasan, motivasi belajar, jenis kelamin, ataupun latar belakang etnis yang berbeda. Fungsi kelompok adalah untuk lebih mendalami materi bersama teman kelompoknya dan lebih khusus untuk mempersiapkan anggota kelompok agar bekerja dengan baik dan optimal pada saat game nanti.

3) Permainan ( Game )

Game terdiri atas pertanyaan-pertanyaan yang dirancang untuk menguji pengetahuan yang didapat siswa dari penyajian kelas dan belajar kelompok. Kebanyakan game ini terdiri dari pertanyaanpertanyaan sederhana bernomor. Siswa memilih kartu bernomor dan mencoba menjawab pertanyaan yang sesuai dengan nomor itu ke dalam kolom penilaian yang sudah disiapkan oleh guru. Siswa yang menjawab benar pertanyaan itu akan mendapatkan skor dan siswa yang menjawab salah tidak mendapatkan skor.

4) Pertandingan ( Tournament)

Untuk memulai turnamen masing-masing peserta mengambil nomor undian. Siswa yang mendapatkan nomor terbesar sebagai reader 1 , terbesar kedua sebagai chalennger 1 , terbesar ketiga sebagai chalenger 2, terbesar keempat sebagai chalenger 3. Dan kalau jumlah peserta dalam kelompok itu lima orang maka yang mendapatkan nomor terendah sebagai reader 2 . Reader 1 tugasnya membaca soal dan menjawab soal pada kesempatan yang pertama. Chalenger 1 tugasnya menjawab soal yang dibacakan oleh reader 1 apabila menurut chalenger 1 jawaban reader 1 salah. Chalenger 2 tugasnya adalah menjawab soal yang dibacakan oleh reader 1 tadi apabila jawaban reader 1 dan 
chalenger 1 menurut chalenger 2 salah. Chalenger 3 tugasnya adalah menjawab soal yang dibacakan oleh reader 1 apabila jawaban readerl, chalenger 1 , chalenger 2 menurut chalenger 3 salah. Reader 2 tugasnya adalah membacakan kunci jawaban. Permainan dilanjutkan pada soal nomor dua. Posisi peserta berubah searah jarum jam. Yang tadi menjadi chalenger 1 sekarang menjadi readerl, chalenger 2 menjadi chalenger 1, chalenger 3 menjadi chalenger 2, reader 2 menjadi chalenger 3 dan reader 1 menjadi reader 2. Hal itu terus dilakukan sebanyak jumlah soal yang disediakan guru.

5) Penghargaan kelompok (team recognise)

Guru

mengumumkan kelompok (team) yang menang dengan perolehan skor tertinggi, dan akan mendapat hadiah atau penghargaan.

\section{METODE PENELITIAN}

Penelitian Tindakan Kelas ( classroom action reseach ) ini dilaksanakan pada kelas yang mempunyai permasalahan dalam pembelajaran yaitu di kelas X MIPA-7 SMA Negeri 1 Kuta Selatan semester I tahun Pelajaran 2016/2017 yang terletak di lantai dua gedung selatan sekolah, yang memiliki ventilasi udara yang bagus sehingga siswa merasa nyaman untuk belajar. Penelitian tindakan kelas ini dilaksanakan selama 3 bulan, yaitu mulai dari bulan September sampai dengan bulan Oktober Tahun 2016, dengan subyek penelitiannya adalah siswa kelas X MIPA-7 SMA Negeri 1
Kuta Selatan semester I tahun Pelajaran 2016/2017 yang berjumlah siswa yang beragama Hindu sebanyak 29 orang.

Sumber data dalam penelitian ini adalah sumber data primer yang diperoleh langsung dari siswa kelas $\mathrm{X}$ MIPA-7 yang dikumpulkan dari siswa meliputi data hasil tes tertulis. Tes tertulis dilaksanakan pada setiap akhir siklus yang mengambil materi wariga. Selain siswa sebagai sumber data primer, penulis juga menggunakan teman sejawat sesama guru sebagai sumber data yang lainnya disamping hasil input data yang dilakukan oleh bagian kurikulum sekolah.

Dalam penelitian ini, alat pengumpulan data berupa tes tertulis diberikan dalam bentuk 10 soal pilihan ganda dan 1 soal uraian pada masingmasing siklus. Soal bentuk uraian menuntut siswa untuk mengingat dan mengorganisasikan gagasan-gagasan atau hal-hal yang telah dipelajari dengan cara mengemukakan atau mengekspresikan gagasan tersebut dalam bentuk uraian tertulis. Lebih khusus lagi tes uraian yang dipilih adalah tes uraian objektif, artinya soal uraian yang memiliki sekumpulan jawaban dengan rumusan yang pasti sehingga dapat dilakukan penskoran secara objektif.

Data yang telah terkumpul dianalisis dengan analisis kualitatif yang sifatnya komparatif untuk kemudian dideskripsikan secara kualitatif berdasarkan skor dan nilai rata-rata yang diperoleh untuk menjelaskan temuan yang didapat. Data yang diperoleh dari hasil tes evaluasi pada akhir masing-masing siklus dianalisis dengan mengkalkulasi nilai rata-rata (mean score) dengan simbol M. Dan hasil tersebut kemudian diinterpretasikan untuk menentukan ketuntasan klasikal (KK) dengan nilai 
kriteria ketuntasan mimimum adalah 67 , dengan rumus sebagai berikut:

$$
\begin{aligned}
M=\frac{\sum x}{N} \quad & \text { Keterangan : } \\
& \text { M = Skor } \\
& \text { rata-rata } \\
& \sum x= \\
& \text { Jumlah total } \\
& \text { skor prestasi } \\
& \text { siswa } \quad= \\
& \mathrm{N} \quad \\
& \text { Jumlah siswa }
\end{aligned}
$$

Banyaknya siswa yang memperoleh nilai $\geq 67$

$\mathrm{KK}=$

$\mathrm{X}$

$100 \%$

$\mathrm{N}$

Keberhasilan penelitian ini dilihat dari rata-rata pencapaian kompetensi yang diperoleh oleh peserta didik, tindakan dianggap sudah berhasil apabila terjadi peningkatan hasil belajar siswa. Apabila siswa (kelas yang diteliti) telah mencapai ketuntasan $85 \%$ atau lebih dengan standar ideal/KKM 67 dan jika peningkatan tersebut dapat dicapai pada tahap siklus 1 dan siklus 2, maka siklus selanjutnya tidak akan dilaksanakan karena tindakan sudah berhasil dan penelitian tindakan kelas yang dilakukan sudah dinilai efektif dan berhasil sesuai dengan harapan.

\section{HASIL PENELITIAN DAN PEMBAHASAN}

Dari hasil penelitian yang dilakukan, pada kondisi awal, siklus I dan siklus II dapat_dilihat bahwa saat kondisi awal rata- rata kelas sebesar 66,21 sedangkan nilai rata- rata kelas siklus I sudah ada peningkatan menjadi 77,59 dan kenaikan nilai rata-rata pada siklus II menjadi 85,00. Untuk lebih jelasnya dapat dilihat pada tabel dibawah ini :

\begin{tabular}{|c|l|c|c|c|}
\hline \multirow{2}{*}{ No } & \multirow{2}{*}{ Uraian } & \multicolumn{2}{|c|}{ Jumlah siswa } & \multirow{2}{*}{$\begin{array}{c}\text { Nilai rata- } \\
\text { rata kelas }\end{array}$} \\
\cline { 3 - 4 } & & Tuntas & Belum Tuntas & \\
\hline 1 & Kondisi Awal & 15 anak & 14 anak & 66,21 \\
\hline 2 & Siklus I & 23 anak & 6 anak & 77,59 \\
\hline 3 & Siklus II & 27 anak & 2 anak & 85,00 \\
\hline
\end{tabular}

Tabel 1. Ketuntasan belajar dan Nilai rata-rata kelas

Dengan jumlah peserta didik yang mendapatkan nilai sangat baik (A) dan baik (B) pada pra siklus, siklus I dan sklus II mengalami peningkatan. Lebih jelasnya dapat dilihat pada tabel dan diagram berikut :

\begin{tabular}{|c|c|c|c|c|c|c|}
\hline \multirow{2}{*}{ NO } & \multirow{2}{*}{ Nilai } & \multirow{2}{*}{ Predikat } & \multirow{2}{*}{ Kategori } & \multicolumn{3}{|c|}{ Jumlah Peserta Didik } \\
\cline { 5 - 7 } & & & & Pra Siklus & Siklus I & Siklus II \\
\hline 1 & $89-100$ & A & Sangat Baik & - & 8 & 12 \\
\hline 2 & $78-88$ & B & Baik & 5 & 6 & 14 \\
\hline 3 & $67-77$ & C & Cukup & 11 & 9 & 1 \\
\hline 4 & $56-66$ & D & Kurang & 11 & 5 & 2 \\
\hline 5 & $<56$ & E & Sangat Kurang & 2 & 1 & - \\
\hline & \multicolumn{3}{|c|}{ Jumlah } & 29 & 29 & 29 \\
\hline
\end{tabular}

Tabel 2. 
Perbandingan jumlah peserta didik pada Pra siklus, Siklus I dan siklus II

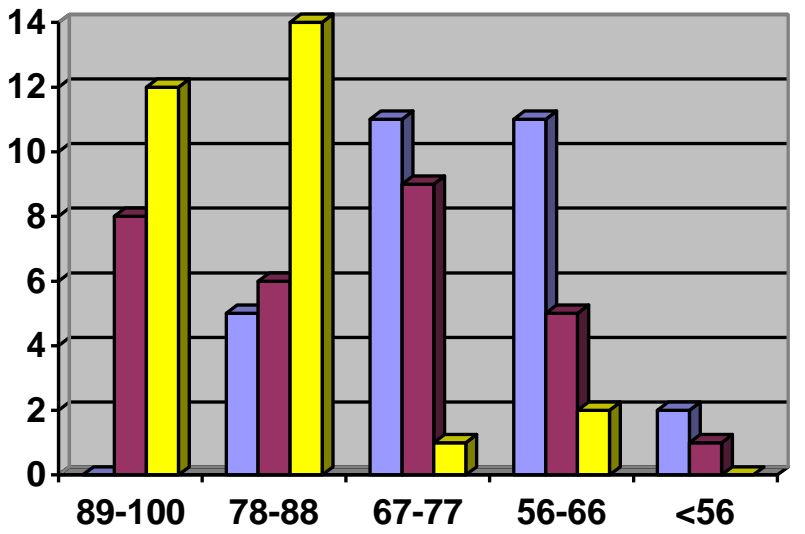

\begin{tabular}{|l|}
\hline Pra Siklus \\
$\square$ Siklus I \\
$\square$ Siklus II \\
\hline
\end{tabular}

Gambar 1. Diagram perbandingan nilai pra siklus, siklus I dan siklus II

Pada awalnya siswa kelas X MIPA-7, nilai rata- rata pelajaran Pendidikan Agama Hindu dan Budi Pekerti rendah. Sebelum dilakukan tindakan guru memberikan tes hasil belajar. Berdasarkan ketuntasan belajar siswa dari jumlah siswa 29 siswa terdapat 15 atau 51,72\% yang baru mencapai ketuntasan belajar. Sedangkan 14 siswa atau 48,28 \% belum mencapai kriteria ketuntasan minimal yang telah ditentukan yaitu sebesar 67. Sedangkan hasil tes pra siklus nilai tertinggi adalah 85 , sedangkan nilai terendah 40, dengan nilai rata-rata klasikal sebesar 66,21.

Dari hasil tes siklus I, menunjukkan bahwa yang mencapai nilai A (sangat baik) adalah 8 siswa $(27,59 \%)$, sedangkan yang mendapat nilai B (baik) adalah 6 siswa atau (20,69\%), sedangkan dari jumlah 29 siswa yang masih mendapatkan nilai C (cukup) sebanyak 9 siswa (31,03\%), dan yang mendapat nilai D (kurang) ada 5 siswa $(17,24$ $\%$ ), sedangkan yang mendapat nilai E (sangat kurang) hanya 1 siswa atau 3,45\%. Terdapat 23 siswa atau 79,31\% yang sudah mencapai ketuntasan belajar. Sedangkan 6 siswa atau 20,69\% belum mencapai ketuntasan. Sedangkan perolehan nilai tertinggi adalah 95, dan nilai terendah 50, dengan nilai rata-rata kelas sebesar 77,59.

Dari pelaksanan tindakan siklus II dapat diketahui bahwa terdapat 27 siswa yang sudah mencapai ketuntasan $(93,10 \%)$ dengan nilai sangat baik (A) adalah 41,38 $\%$ atau 12 siswa, sedangkan yang terbanyak yaitu yang mendapat nilai baik (B) adalah 48,28 \% atau 14 siswa. Dan yang mendapat nilai C (cukup) adalah 3,45\% atau hanya 1 siswa. Sedangkan yang mendapat nilai D sebanyak 2 siswa atau 6,90\% dan nilai E (sangat kurang) tidak ada. Sedangkan nilai rata-rata kelas sebesar 85,00.

\begin{tabular}{|c|c|c|}
\hline Pra Siklus & Siklus I & Siklus II \\
\hline$=15(51,72 \%)$ & $=23(79,31 \%)$ & $=27(93,10 \%)$ \\
\hline$\sim$ Belum tuntas $=14(48,28 \%)$ & $\sim$ Belum tuntas $=6(20,69 \%)$ & $\sim$ Belum tuntas $=2(6,90 \%)$ \\
\hline & $\begin{array}{l}\text { Refleksi: } \\
\text { Peningkatan ketuntasan }= \\
27,49 \% \\
(79,21-51,72=27,49 \%)\end{array}$ & $\begin{array}{l}\text { Refleksi } \\
\text { Peningkatan ketuntasan = } \\
13,79 \% \\
(93,10-79,31=13,79 \%)\end{array}$ \\
\hline Nilai Tertinggi $=85$ & Nilai Tertinggi $=95$ & Nilai Tertinggi $=100$ \\
\hline Nilai terendah $=40$ & Nilai terendah $=50$ & Nilai terendah $=60$ \\
\hline
\end{tabular}




\begin{tabular}{|l|l|l|}
\hline Nilai rata-rata $=66,21$ & Nilai rata- rata $=77,59$ & $*$ Nilai rata- rata $=85,00$ \\
\hline & Refleksi : & Refleksi : \\
& Peningkatan nilai rata- rata & Peningkatan nilai rata- rata \\
$=11,38$ & 7,41 \\
& $(77,59-66,21=11,38)$ & $(85,00-77,59=7,41)$ \\
\hline
\end{tabular}

Tabel 3.

\section{E. PENUTUP}

Perbandingan hasil belajar pada pra siklus, siklus I dan siklus II
Penerapan Model Pembelajaran Kooperatif Teams Games Tournaments (TGT) dapat meningkatkan hasil belajar mata pelajaran Pendidikan Agama Hindu dan Budi Pekerti khususnya kompetensi dasar wariga bagi siswa kelas X MIPA-7 SMA Negeri 1 Kuta Selatan Semester I Tahun Pelajaran 2016/2017. Pada akhir siklus I, siswa yang mencapai ketuntasan belajar sebanyak 79,31\% (23 siswa), dan siswa yang belum tuntas sebanyak 20,69\% (6 siswa), sedangkan pada akhir siklus II, siswa yang mencapai ketuntasan belajar sebanyak 93,10\% (27 siswa) dan sebanyak 6,90\% (2 siswa) yang belum mencapai ketuntasan belajar, terjadi peningkatan ketuntasan belajar sebesar $13,79 \%$.

Dengan nilai rata- rata kelas siklus I sebesar 77,59 dan nilai rata- rata kelas siklus II 85,00 terjadi peningkatan nilai rata-rata kelas sebesar 7,41. Adapun hasil pengamatan proses belajar menunjukkan perubahan siswa lebih aktif selama proses pembelajaran berlangsung jika dibandingkan dengan kondisi awal.

Diharapkan para Guru perlu membuat persiapan yang matang dan Pemerintah sebagai pemegang kebijakan ataupun instansi lain yang terkait agar memperhatikan Guru baik material maupun spiritual dalam melakukan penelitian khususnya Penelitian Tindakan Kelas sebagai tuntutan dalam pembelajaran inovatif yang berkembang pada masa sekarang ini untuk meningkatkan kualitas pendidikan.

\section{DAFTAR PUSTAKA}

Arikunto, Suharsini, 1991. Prosedur Penelitian : Suatu Pendekatan Praktek. Jakarta Rineka Cipta

Dimyati dan Mudjiono, 1992. Strategi Belajar Mengajar. Jakarta. Depdikbud.

Oemar Hamalik.1993. Metode Mengajar dan Kesulitan-Kesulitan Belajar. Bandung: Tarsito.

PHDI, 2000. Himpunan Keputusan Seminar Kesatuan Tafsir Terhadap Aspek-Aspek Agama Hindu I-XV, Denpasar : Proyek Peningkatan Sarana Dan Prasarana Kehidupan Beragama.

Sudirga, Ida Bagus \& I Nyoman Yoga segara, 2014. Pendidikan Agama Hindu dan Budi Pekerti SMA/SMK kelas X. Jakarta : Kementerian Pendidikan dan Kebudayaan.

http://modelpembelajarankooperatif.blogs pot.co.id/2012/08/teams-gamestournaments-tgt.html, diunduh tanggal 23 Oktober 2016 